\title{
RESTRICTION OF THE DIVIDENDS RIGHT OF A MINORITY SHAREHOLDER
}

\author{
Cristian MARES* \\ Andra-Cristina ONOFREI**
}

\begin{abstract}
This study examines the issue of distributing dividends to the shareholders in an amount lower than that relating to the number of shares held in the company, in the context in which the decision regarding the distribution of dividends belongs to the general meeting of the shareholders. Law No. 31/1990 of companies allows the distribution of dividends to the shareholders in a different amount from their participation quota in the paid-up share capital, but only under certain special conditions. Such an uneven or unfair distribution must be decided by the vote of all the shareholders of the company and without infringing the ownership right over the shares. According to article 67 of Law No. 31/1990, the shareholders of a company are the beneficiaries of a share of the profit, respectively the dividends, in principle in proportion to the participation quota in the paid-up share capital, as provided for in the articles of incorporation. However, this rule also bears some exceptions, but without prejudice to the ownership of shares enjoyed by shareholders (provisions also covering limited liability companies). The general meeting of shareholders cannot establish a fixed amount constituting the amount of the dividends, since they are determined mainly annually, depending on the profit made by the company, by reference to the financial statements and whether or not the shareholders' decision to reinvest the profit obtained was adopted.
\end{abstract}

Keywords: dividends, abuse majority, social interest, general meeting of shareholders, good faith, unanimity, competent court of law

DOI: 10.53373/ VULS.2021.38.2.005

\section{Introduction}

In the beginning, we shall highlight the relevant provisions of Companies Law No. $31 / 1990^{1}$ (hereinafter "Law No. 31/1990") with respect to the right to dividends and their distribution among the shareholders of a company.

According to article 67 paragraphs (1) and (2) of Law No. 31/1990, the dividend represents the share of profit that is paid to each shareholder. Thus, dividends are distributed to the shareholders proportionally to the quota in the paid-up share capital, optionally quarterly based on interim and annual financial statements, after regularization through annual financial statements, unless otherwise provided in the articles of incorporation. Dividends may be paid optionally quarterly within the term established by the general meeting of shareholders or by special laws; the regularization of the differences resulting

* Lecturer PhD, Faculty of Law and Administrative Sciences, "Valahia" University of Târgoviște; Partner, Mareș \& Mareș Law Firm (email: cristian.mares@mares.ro).

* Senior associate, Mareș \& Mareș Law Firm (email: cristina.onofrei@mares.ro).

${ }^{1}$ Republished in Official Gazette of Romania No. 1066 of November 17, 2014. 
from the distribution of dividends during that year will be done through the annual financial statements. The payment of the differences resulting from the regularization is made within 60 days from the date of approval of the annual financial statements related to the closed financial year. Otherwise, the company owes, after this term, a default interest calculated according to art. 3 of Government Ordinance No. 13/2011 regarding the legal remunerative and penalizing interest on pecuniary obligations, as well as for the regulation of some financial - fiscal measures in the banking field ${ }^{2}$, if by the articles of incorporation or by the decision of the general meeting of shareholders that approved the financial statements was not determined a higher interest ${ }^{3}$.

When a partial distribution of dividends is made between shareholders during the financial year, the annual financial statements will highlight the partially assigned dividends and will settle the resulting differences accordingly 4 .

If the shareholders owe dividend refunds, following the regularization operated in the annual financial statements, they shall be paid to the company within 60 days of the date of approving the annual financial statements. Otherwise, the shareholders will owe, after this term, as the company does in the abovementioned situation, a penalty interest calculated according to article 3 of Government Ordinance No. 13/2011, if by the articles of incorporation or by the decision of the general meeting of shareholders that approved the financial statements related to the terminated financial year, a higher interest rate has not been determined.

Dividends may be distributed only from profits determined by $l a w^{5}$. In case dividends have been paid contrary to the abovementioned provisions, they shall be reimbursed, if the company proves that the shareholders were aware of the irregularity of the distribution or, given the circumstances, they should have been aware of it $^{6}$.

The right to claim the reimbursement of dividends that have been paid against the legal provisions shall be limited to 3 years from the date of their distribution ${ }^{7}$.

The due dividends after the assignment of the shares belong to the assignee, unless otherwise agreed by the parties ${ }^{8}$.

According to article 94 paragraph (1) of Law No. 31/1990, the shares must be equal in value; they grant equal rights to the owners. However, if the articles of incorporation allow, certain categories of shares conferring different rights to their holders may be issued, according to the provisions of articles 95 and $96^{9}$.

Preferred shares benefiting from priority dividends without voting right may be issued; they grant the holder ${ }^{10}$ :

a) the right to a priority dividend levied over the distributable profit of the financial year, before any other payments;

b) the recognized rights of the shareholders with ordinary shares, including the right to participate in the general meeting, except for the voting right.

${ }^{2}$ Published in Official Gazette of Romania No. 607 of August 29, 2011.

${ }^{3}$ Article 67 paragraph $\left(2^{1}\right)$ of Law No. 31/1990.

${ }^{4}$ Article 67 paragraph $\left(2^{2}\right)$ of Law No. 31/1990.

${ }^{5}$ Article 67 paragraph (3) of Law No. 31/1990.

${ }^{6}$ Article 67 paragraph (4) of Law No. 31/1990.

${ }^{7}$ Article 67 paragraph (5) of Law No. 31/1990.

${ }^{8}$ Article 67 paragraph (6) of Law No. 31/1990.

${ }^{9}$ Article 94 paragraph (2) of Law No. 31/1990.

${ }^{10}$ Article 95 paragraph (1) of Law No. 31/1990. 
Shares with a priority dividend, without voting rights, may not exceed one quarter of the share capital and will have the same nominal value as ordinary shares ${ }^{11}$.

The directors, managing directors, members of the board of directors and of the supervisory board, as well as the auditors of the company may not hold shares with priority dividend without voting right ${ }^{12}$.

In case of delay in paying the dividends, the preferred shares shall acquire the voting right, starting from the due date of the obligation to pay the dividends that shall be distributed during the following financial year or, if the general meeting decides that dividends are not to be distributed the following year, starting from the date of publication of the general meeting's decision, until the effective payment of the outstanding dividends ${ }^{13}$.

Preferred shares and ordinary shares may be converted from one category into the other by decision of the extraordinary general meeting of the shareholders, adopted in accordance with article $115^{14}$.

The holders of each category of shares shall meet during special meetings, under the terms provided by the company's articles of incorporation. Any holder of such shares may attend these special meetings ${ }^{15}$.

Article $136^{1}$ of Law No. $31 / 1990$ stipulates that the shareholders shall exercise their rights in good faith, by observing the rights and the legitimate interests of the company and those of the other shareholders.

\section{The dividends}

Before analyzing of the proposed subject, we need to clarify the notion of "dividends". Thus, the dividends represent the company's profit, distributed between shareholders either in cash or through equity titles. It is for this reason that the dividend policy achieves so much attention, as the distribution of dividends can be one of the incentives for shareholders who decide to invest in the company.

The doctrine ${ }^{16}$ has defined the dividend as "the part of the net profit due to the shareholders after the termination of the financial year, determined by the class and by the number of owned shares, based on the decision of the general meeting of the shareholders". The right to the dividend is "a subjective, relative, personal, patrimonial, subsidiary right of ownership over the shares, affected by a double suspensive condition: (i) the registration of profit by the company and (ii) the distribution of this profit as dividends"17.

Obviously, as it results from the abovementioned legal provisions, the dividends are distributed only from the real and useful profit, and not from a fictitious, uncertain, or nonexistent one. The High Court of Cassation and Justice ${ }^{18}$ also ruled in this respect, noting that

${ }^{11}$ Article 95 paragraph (2) of Law No. 31/1990.

${ }^{12}$ Article 95 paragraph (3) of Law No. 31/1990.

${ }^{13}$ Article 95 paragraph (4) of Law No. 31/1990.

${ }^{14}$ Article 95 paragraph (5) of Law No. 31/1990.

${ }^{15}$ Article 96 of Law no. 31/1990.

${ }^{16}$ C. Duțescu, Drepturile acționarilor, Ed. Lumina Lex, București, 2006, p. 296

17 Idem, p. 297.

${ }^{18}$ High Court of Cassation and Justice, $2^{\text {nd }}$ Civile Section, decision no. 1246/2011, www.scj.ro, accessed on December 3, 2021. 
the requirement provided by article 67 paragraph (3) of Law No. 31/1990 for the approval of the dividend distribution is the legal determining of the profit.

The profit is real when "an income has been obtained from the commercial activity of the company which, entering the patrimony of the company, exceeds the share capital. Only when there is a surplus the dividends may be distributed"19.

Profit is useful when "it represents the remaining profit after the distribution by the legal purposes: the fulfillment of the share capital, the payment of taxes and duties and other debts of the company etc." 20

As it is a legal-accounting operation to determine the destination of the positive result of the financial year of one year or of more years, the general meeting of the shareholders may not establish a fixed amount that constitutes the value of dividends, since they are established annually (mainly), depending on the achieved profit, by reference to the financial statements and whether or not the decision to reinvest the profit is adopted, holding reserves etc.

It is a practice among the small companies, especially in the first years of activity, to distribute dividends annually, but sometimes the general meeting of the shareholders may decide not to distribute the dividends and to keep the profit in full in order to reinvest it, which generates the premises for even higher revenues in the future.

It was also noted in case law ${ }^{21}$ that for the payment of dividends is not sufficient only to approve the financial statements and a period of six months from their approval, but it should also be accomplished the requirement to approve the distribution of profits as dividends to the shareholders, and not to withhold the profit or the dividends for reinvestment.

From another perspective, the dividends are also aimed at taking a risk on behalf of the shareholders who, although initially invest a certain amount of money in the company, the obtained profit may not be in accordance with their expectations due to the economic and investment factors.

\section{The distribution of dividends. Restriction of the dividends right}

Moreover, article 1902 paragraph (1) of Civil Code provides that the participation to the company's profit also involves the contribution to its losses, under the conditions provided by the articles of incorporation, of the Civil Code or of other applicable legal provisions, as the case may be.

As mentioned above, according to article 67 paragraph (2) of Law No. 31/1990, the articles of incorporation of the company may provide that the distribution of dividends between shareholders shall take place in other participation quota in the paid-up share capital than their contribution to the share capital, within reasonable limits.

However, in violation of equal rights of the shareholders, there have been situations where the right to dividends has been disproportionately restricted by their improper distribution, without a decision of the general meeting of the shareholders adopted unanimously in this respect.

\footnotetext{
${ }^{19}$ St.D. Cărpenaru, Comentariu (la art. 67) in St.D. Cărpenaru, Gh. Piperea, S. David, Legea societăților. Comentariu pe articole, ed. a V-a, Ed. C.H. Beck, București, 2014, p. 243.

${ }^{20}$ Idem.

${ }^{21}$ High Court of Cassation and Justice, $2^{\text {nd }}$ Civile Section, decision no. 2651/2011, www.scj.ro, accessed on December 3, 2021.
} 
Nevertheless, as stated in the doctrine ${ }^{22}$, the general meeting may not infringe the right to dividends as it would be absurd to believe that a person enters a company and makes a contribution, on behalf of a spirit of freedom, since the right to dividends is a fundamental essential right representing the reason for which the shareholders understood to acquire this quality.

Thus, the enforcement of subjective rights becomes abusive whenever they are either not exercised in good faith, but, on the contrary, their exercise is done for a purpose contrary to the intended purpose at the time of acquiring the quality of shareholder, or when their exercise affects the rights and the interests of the company and those of other shareholders. These two situations regulated by article $136^{1}$ of Law No. 31/1990 concern precisely the doctrinal conceptions regarding the abuse of rights, respectively the objective conception that implies the diversion of rights from the socio-economic purpose considered by the legislator and the subjective vision that implies the exercise of rights to harm the others ${ }^{23}$.

In other words, when the general meeting of the shareholders decides to distribute the dividends to some of the shareholders in other participation quota in the paid-up share capital than their contribution to the share capital, it is necessary to establish the purpose or the reason considered by the general meeting, which is relevant for the amendment of the articles of incorporation that extremely infringes the right to dividends.

Such decision of the general meeting affects the ownership right of the shareholders with respect to the shares already issued and owned by them because it unduly changes the possibility to value the profit generated by the company and the procedure of capitalization of rights by the shareholder, including by reducing the civil fruits generated by those shares.

We share the doctrine's opinion ${ }^{24}$ that the derogation from the regulation of proportional profit distribution, even if it is a statutory provision, it is not subject to the majority rule, but it must be decided unanimously by the shareholders given that it affects the individual corporate rights of each shareholder, as they result from the law, according to the principle referred to in article 94 paragraph (1) $2^{\text {nd }}$ thesis and article 210 paragraph (4) of Law No. $31 / 1990$.

Once the distribution decision has been adopted, the right to dividends materializes as a form of an individual receivable right of the shareholders towards the company. At this point, the shareholder becomes a creditor of the company and has the same rights as any other unsecured creditor, within the general three-year limitation period, starting on the due date of the obligation to pay dividends. ${ }^{25}$

It should be noted that those agreements that favor some shareholders at the expense of others (with reference to the leonine clauses - into Romanian "clauze leonine") have nothing in common with the free will consent of some shareholders, who may solely decide on the distribution of dividends in other participation quota in the paid-up share capital than their contribution to the share capital. ${ }^{26}$

22 I.L.Georgescu, Drept comercial român, $2^{\text {nd }}$ Vol., Ed. C.H. Beck, București, 2002, p. 302, apud L. Săuleanu, Societățile comerciale: adunările generale ale acționarilor, Ed. Hamangiu, București, 2008, nota 2, pag. 41.

${ }^{23}$ I. Deleanu, Drepturile subiective şi abuzul de drept, Ed. Dacia, Cluj-Napoca, 1988, p. 51.

${ }^{24}$ S. Bodu, Proporționalitatea distribuirii dividendelor. Distribuirea neproporțională. Cotele de fondator, in Romanian Business Law Review No. 6/2014, p. 89.

${ }^{25}$ St. D. Cărpenaru, Comentariu (la art. 67) in St. D. Cărpenaru, S. David, C. Predoiu, Gh. Piperea, Legea societăților comerciale. Comentariu pe articole, $4^{\text {th }}$ Edition, Ed. C.H. Beck, București, 2009, p. 268.

${ }^{26}$ S. Deleanu, Clauza leonină în contractele de societate, in Law Review No. 2/1992, p. 38. 
As long as the parties of the articles of incorporation of a company freely express their agreement and the law allows this, the decision to distribute dividends in other participation quota in the paid-up share capital than their contribution to the share capital is a legal one and there shall be no issue regarding: (i) agreements that favor some shareholders at the expense of others or (ii) the existence of leonine clauses.

The case law $^{27}$ also stated that the receivable right of the shareholders against the company, which has a correlative obligation to pay it, arises only after the dividend has been approved by the general meeting of the shareholders, and the payment will be made under the approved conditions and within the approved deadlines, which, however, may not exceed 6 months from the date of approval of the annual financial statement for the terminated financial year. Thus, the High Court of Cassation and Justice stated that the 6-month period runs only if the amount of dividends has been established in advance by the general meeting of the shareholders, a primary condition for their subsequent distribution. On the contrary, if the general meeting of the shareholders decides to reinvest the profit, based on an objective justification in this regard, such decision does not lead per se to the conclusion that the provisions of article 67 of Law No. 31/1990 are infringed.

It should be noted that the legislator regulated within article 67 paragraph (5) of Law No. $31 / 1990$ only the fact that the right to dividends' restitution, paid by violating provisions of paragraphs (2) and (3) of article 67, is under the civil statute of limitation for civil court claims of three (3) years from the date of their distribution, but he did not explicitly specify the civil statute of limitation period when the damaged shareholder may sue the company for the payment of due dividends. In our opinion, the civil statute of limitation for civil court claims of three (3) years starting the date when the company had to pay the due dividends to the shareholder also applies in this case.

Given that part of the shareholder's satisfaction and motivation is the collection of dividends, it is obvious that any shareholder will request the collection of dividends in the maximum quota, proportional to the participation to the share capital, and the restriction of this right is expected to affect the shareholder's patrimony.

The payment term of dividends, as well as the time limit for the reimbursement of dividends by the shareholders, should also be taken into account if there have been differences as a result of regularizations. According to article 67 paragraph (2) and article 67 paragraph (22) of Law No. 31/1990, in case the company or shareholders owe restitution of dividends, calculated following the regularization operated in the annual financial statements, they are paid to shareholders or to the company within 60 days from the date of approval of the annual financial statements. In case of non-payment in time, the company or the shareholders, as the case may be, owe, after this deadline, a penalty interest calculated according to article 3 of Government Ordinance No. 13/2011, if by the articles of incorporation or by the decision of the general meeting of the shareholders that approved the financial statements related to the terminated financial year, a higher interest rate has not been established.

As provided by article $136^{1}$ of Law No. 31/1990, good faith, as condition of exercising the rights, has the purpose of "rebalancing the contractual relations affected by the legal,

${ }^{27}$ High Court of Cassation and Justice, $2^{\text {nd }}$ Civile Section, decision no. 2490/2010, www.scj.ro, accessed on December 3, 2021. 
economic and informational inequality between the parties, recognizing its universal vocation to complete the legal provisions". ${ }^{28}$

The exercise of rights in good faith has been interpreted in the light of an obligation of loyalty that is mandatory to the shareholders in relation with the other shareholders and with the company, but also to the company towards the shareholders, and which is the consequence of their common intention to carry out jointly the commercial activity for the purpose of obtaining benefits (affectio societatis).

In order to establish unequivocally the scope of good faith, the legislator explicitly regulated per a contrario the abuse of rights as that exercise of a right by its holder, contrary to good faith, in order to harm or to damage another or in an excessive and unreasonable manner.

Regarding the excess of power theory, an author ${ }^{29}$ stipulated that said theory has the purpose to particularize the definition of the legal control, explaining that: "excess of power is a kind of occult defect, because it consists in a contradiction between the form of the act and its substance. The vitiated act by the excess of power has an honest face, which hides harmful resolutions". Thus, the analyze of the decision of the general meeting of the shareholders according to this view has also been adopted by Italian case law ${ }^{30}$ : "therefore, in order to establish the abuse, we shall observe and touch the substance of the act and not its form and, in addition, we shall investigate the reasons and the purposes that determined the decision and the judge will not be able to do this research except by researching the merits of the case law".

As noted in the case law ${ }^{31}$, it is relevant the point of view that the principle of majority governance, even when the law allows certain restrictions on the exercise of some rights, it must be in the interest of all shareholders and, in no case, it can be used for the purpose to favor the majority shareholder. For the same reasoning, it was mentioned that the power that the articles of incorporation and the legal organization of the company gives to some of the shareholders should not be diverted on the principle that the minority obeys the majority or, in other words, for the sole purpose of favoring the majority over minority, considering that a decision is adopted because it is in line with both the social interest and the interests of the shareholders.

Moreover, a decision of the general meeting of the shareholders adopted under such conditions reflects an abuse of majority harming the social interest and the common interest of the shareholders. The doctrine ${ }^{32}$ substantiates the social interest on the harmonious synthesis between the interest of the shareholders and the interest of the company. At the same time, the doctrine ${ }^{33}$ also explained that the abuse of power meets the conditions of tortious civil liability, the first legal sanction being the annulment of the decision of the general meeting of the shareholders adopted in this regard.

In France, the Court of Cassation has constantly considered that the abuse of majority exists when a decision has been adopted contrary to the general interest of the company and

${ }^{28}$ I. Popa, Reprimarea clauzelor abuzive, Pandectele Române No. 2/2004, p. 196.

${ }^{29} \mathrm{~S}$. Bodu, Abuzul de dreptul de vot, article published on www.juridice.ro, accessed on December 3 , 2021.

30 Idem.

${ }^{31}$ High Court of Cassation and Justice, $2^{\text {nd }}$ Civile Section, decision no. 570/2010, www.scj.ro, accessed on December 3, 2021.

${ }^{32}$ R.N. Catană, Rolul justiției în funcționarea societăților comerciale, Ed. Lumina Lex, București, 2003, p. 238 și 242.

${ }^{33}$ R.N. Catană, op. cit., p. 264 și 281. 
for the sole purpose of favoring the members of the majority over the minority ${ }^{34}$. This jurisprudential definition has highlighted the conflict of interests between the shareholders, so that the principle of majority governance, intended to serve the interests of all shareholders, is misappropriated, being used for the sole purpose of favoring members of the majority over the minority.

Thus, the restriction of the right to dividends, when disproportionately made, violates: (i) the provisions of article 94 paragraph (1) of Law No. 31/1990, according to which the shares grant the owners' equal rights and (ii) the provisions of article 15 of the Civil Code, according to which no right can be exercised in order to harm another or in an excessive and unreasonable manner, contrary to good faith.

For example, in the literature ${ }^{35}$ it has been provided that the dividends may not be paid in other participation quota in the paid-up share capital than their contribution to the share capital, since: (i) the law prohibits so-called leonine clauses, i.e. those agreements which favor some shareholders at the expense of others, and, also (ii) article 1513 of the Civil Code stipulates that the articles of incorporation by which a shareholder establishes all his earnings is null and void. Also, the agreement based on which it is agreed that one or more shareholders should be exempted from losses participation is null and void.

It is also important to note that the principle of majority governance must be in the interest of all shareholders and, in no case, it can be used in order to favor the majority. For the same reasoning, it should be noted that the power that the articles of incorporation and the legal organization of the company give to some of the shareholders should not be diverted on the principle that the minority obeys the majority or, in other words, for the sole purpose of favoring the majority over the minority, given that a decision is adopted because it is in line with both the social interest and the interests of shareholders ${ }^{36}$.

This issue has also been analyzed in recent case law. By Sentence No. 27/2021 rendered by Mures Specialized Tribunal ${ }^{37}$, the court decided in favor of a shareholder, who criticized the decision of the general meeting of the shareholders by which his right to dividends was unfoundedly and illegally restricted, by establishing that only he would benefit from dividends in the share of $1 / 4$ of his share participation in the share capital.

The claimant, shareholder of the defendant company, reasoned his claim for the annulment of the decision of the general meeting of the shareholders that amended the articles of incorporation regarding the distribution of dividends also on the fact that said claim was in fact his will to ensure that the company operated legally, in the interests of all shareholders, and made several requests for information, to which he received no response from management (which, in fact, should have be answered by the majority shareholders).

In this case, the court stipulated that the allegation was that, by virtue of the proportionality of the voting right, the majority shareholders, in majority connivance, without any rational reason, amended the company's provision reflecting the patrimonial scope of corporate law - the right to dividends - breaking the social balance exclusively into the

${ }^{34}$ Paris Court of Appel, December 17, 1991, Bull. Joly 1992, p. 297/ Dominique Schmidt, apud L. Săuleanu in Exercitarea abuzivă a dreptului de vot. Abuzul de majoritate și abuzul de minoritate, www.drept.ucv.ro, accessed on December 3, 2021.

${ }^{35}$ L. Grigorie, Plata dividendelor în cote diferite față de cotele de participare a asociațiilor la capitalul social, www.legestart.ro, accessed on December 3, 2021.

${ }^{36}$ High Court of Cassation and Justice, $2^{\text {nd }}$ Civile Section, dec. no. 570/2010, www.scj.ro, accessed on December 3, 2021.

${ }^{37}$ Mures Specialized Trib., Sent. no. 27/2021, www.sintact.ro, accessed on December 3, 2021. 
detriment of the claimant (being violated inclusively the provisions of articles 95-96 of Law No. 31/1990, which regulate the category of preferred shares, respectively those with priority dividend, with no voting rights): "The court wants to remind the fact that the legislator, regulating the rights arising from the property over a share in a company thus incorporated, i.e. joint stock company, preserved the common rule of equality, establishing by the provisions of article 94 paragraph (1) of Law No. 31/1990: <grants the owners equal rights>".

There are exceptions from this rule, but only under the conditions provided by the articles 95-96 of Law No. 31/1990, which regulate the category of preferred shares, respectively those with the right of priority dividend, without the voting right.

These conditions concern: (i) the weight of such shares - which may not exceed one quarter of the share capital; (ii) the value of the shares - equal to the ordinary ones; (iii) operating some prohibitions - persons who can control the company are not allowed to hold such preferred shares and (iv) the transparent creation of shares decided by the resolution of the general meeting of the shareholders, according to the provisions of article 115 of Law No. 31/1990.

Strictly under the pecuniary issue of the company's rights, the provisions of article 67 paragraph (2) of Law No. 31/1990 are very relevant, because they establish the same rule of proportionality with the participation quota in the paid-up share capital, from which it could be abdicated only as a result of the will of the shareholders expressed by the articles of incorporation.

Thus, the corporate dispute is reduced to understanding the manner in which the nonpecuniary part of the corporate law - the voting right - could interfere with the pecuniary one - the right to dividends.

Mureș Specialized Tribunal also ruled that, strictly under the pecuniary aspect of the company's rights, there are relevant the provisions of article 67 paragraph (2) of Law No. $31 / 1990$, which establish the same rule of proportionality of the collection of dividends with the the participation quota in the paid-up share capital, from which it could be abdicated only as a result of the will of the shareholders expressed by the articles of incorporation.

The court also applied the provisions of article 14 of the Civil Code regarding bona fide and explained that, per a contrario, the abuse of rights is the exercise of a right by its holder, contrary to good faith, for the purpose of harming another in an excessive and unreasonable way: "From this point of the analysis, the provisions of article $136^{1}$ of Law No. 31/1990 become relevant, which set out the essential objective standards with value of principle regarding the possibility of the shareholders to exercise their rights within the company, respectively: (i) in good faith, (ii) with respect for the rights and the legitimate interests of the company, first and foremost and (iii) subsequently, of the other shareholders. Moreover, this substantial corporate provision only reflects bona fide - good faith, a fundamental principle thus outlined by the provisions of article 14 of the Civil Code, on which the positive material law is built".

Combining the provisions of article $136^{1}$ of Law No. 31/1990 with those of articles 14 and 15 of the Civil Code (2009), the judge underlines the conditions under which the shareholders should exercise their rights recognized by the legislator and by the articles of incorporation of the company: (i) principally, in good faith; (ii) taking into account primarily the legitimate interests and rights of the company; (iii) subsequently the legitimate interests and rights of the other shareholders; (iv) without injuring or damaging the latter to an excessive and unreasonable extent. 
Since good faith operates essentially as an assumption that can be overturned, it is necessary to identify those circumstances that would be capable of overturning it. For that reason, only after all the other issues in question have been examined in the light of the factual situation, it will be possible to examine it judiciously.

Moreover, the abovementioned Court also ruled that the distribution of dividends in a disproportionately small amount to a shareholder, and in particular to the minority shareholder, could even reveal a harassing purpose, hostility, following the claimant's attempts to be informed of the important aspects of the management of the defendantcompany, by the persons who, in a non-transparent manner, socially and executively dominate the defendant-company, the latter also being those who voted to amend the articles of incorporation regarding the right to dividends strictly in the detriment of the minority shareholder, the claimant.

In this decision, the Court also acknowledged that the amendment of the articles of incorporation as indicated above was not justified by an interest of the defendant-company other than the preservation of funds solely by constantly damaging the claimant's corporate rights: "to cover supposed imminent losses that will suffer as a result of the pandemic (a notorious event), without actually revealing the circumstances that would adversely affect the professional activity of the defendant-company".

Thus, the Court concluded that, for no apparent reason and implicitly, the amendment of the defendant-company's articles of incorporation created de facto a preferred category of shares with priority right to dividends: "without a correction in the absence of the voting right and with disregard of the interdiction on behalf of the persons who exercises the executive control of the company, i.e. without observing the essential conditions required by the provisions of articles $95-95$ of Law No. 31/1990", the damage to the claimant-shareholder is direct, immediate and clearly excessive.

Such conduct was sanctioned by the Court with the annulment of the decision of the general meeting of the shareholders which unjustifiably amended the company's articles of incorporation at the expense of the minority shareholder regarding the right to dividends, given that equality between the rights of the shareholders have the main purpose to eliminate any discrimination between the shareholders of the same company.

It is unfortunate that, although the Court rendered the abovementioned decision, it has limited effectiveness because it may not replace the shareholders' will, expressed by a vote at the next general meeting of the shareholders by which it will be established again the way in which the dividends will be distributed. However, the doctrine ${ }^{38}$ stated that the control made by the court: "generally involves a control of necessity with regard to the decisions that had been taken".

\section{Conclusions}

The provisions of the special law (Law No. 31/1990), but also those of the Civil Code prohibit the violation of equal rights of the shareholders regarding the dividend policy and their unfair distribution to the shareholders, without a decision of the general meeting of the shareholders adopted unanimously in this regard.

${ }^{38}$ S. Bodu, Abuzul de dreptul de vot (2), www.juridice.ro, accessed on December 3, 2021. 
The social interest has priority over any private interests of shareholders, and the social interest is, according to the doctrine ${ }^{39}$, the expression of the interests of shareholders subject to the concept of affectio societatis, so that the common intention of shareholders to associate and conduct a joint business to obtain profit metamorphoses as the direction and purpose of the company; for this common purpose, it draws its foundation and the idea of sanctioning those cases in which, as a result of the vote, certain shareholders are favored, through abuse of rights and power.

It is true that the legislator has allowed the implementation of the principle of majority governance, but even when the law allows certain restrictions in the exercise of certain rights, they must be in the interest of all shareholders and, in no case, it can be used to favor the majority shareholder.

However, a distribution of dividends in a different percentage or amount as the shareholder's participation, without the prior shareholder's consent, represents a form of an abuse of rights, and the decision of the general meeting of the shareholders by which the unfair distribution of the dividends was decided should be annulled by the competent court of law.

\section{Bibliography:}

1. S. Bodu, Proporționalitatea distribuirii dividendelor. Distribuirea neproporțională. Cotele de fondator, in Romanian Business Law Review No. 6/2014.

2. S. Bodu, Abuzul de dreptul de vot, article published on www.juridice.ro, accessed on December 3, 2021.

3. R.N. Catană, Rolul justiției în funcționarea societăților comerciale, Ed. Lumina Lex, București, 2003.

4. St. D. Cărpenaru, Gh. Piperea, S. David, Legea societăților. Comentariu pe articole, ed. a V-a, Ed. C.H. Beck, București, 2014.

5. Deleanu, Drepturile subiective şi abuzul de drept, Ed. Dacia, Cluj-Napoca, 1988.

6. S. Deleanu, Clauza leonină în contractele de societate, in Law Review No. 2/1992.

7. C.Duțescu, Drepturile acționarilor, Ed. Lumina Lex, București, 2006.

8. I.L Georgescu, Drept comercial român, $2^{\text {nd }}$ Vol., Ed. C.H. Beck, București, 2002.

9. L.Grigorie, Plata dividendelor în cote diferite față de cotele de participare a asociațiilor la capitalul social, www.legestart.ro, accessed on December 3, 2021.

10. I. Popa, Reprimarea clauzelor abuzive, Pandectele Române No. 2/2004.

11. L.Săuleanu, Societăţile comerciale: adunările generale ale acționarilor, Ed. Hamangiu, București, 2008.

12. L.Săuleanu in Exercitarea abuzivă a dreptului de vot. Abuzul de majoritate şi abuzul de minoritate, www.drept.ucv.ro, accessed on December 3, 2021.

\footnotetext{
${ }^{39}$ L. Săuleanu, Exercitarea abuzivă a dreptului de vot. Abuzul de majoritate și abuzul de minoritate, www.drept.ucv.ro, accessed on December 3, 2021.
} 